\title{
MENGGAGAS ALTERNATIF PEMIKIRAN ASWAJA DI TENGAH KEHIDUPAN MASYARAKAT BERBASIS PESANTREN
}

\author{
Oleh : Mohammad Asrori Alfa
}

\begin{abstract}
ABSTRAK
Pemahaman konsep Ahlussunnah Wal J ama'ah selama ini, sering dipahami sebagai doktrin ideologi komunitas tertentu. Akibatnya, banyak terjadi b entuk kesalahpahaman d an keresahan yang berimbas s osiocultur, sosio-politik, dan sosiso-psychologic di tengah perkembangan kehidupan umat manusia. Sesunguhnya substansialisme nilai Aswaja itu sendiri bisa dijadikan tolok ukur (mi' yar) sarana metodologi berpikir (manhaj al-fikr) dalam berbagai aspek kehidupan manusia secara mikro maupun makro, hal ini $k$ ita d apat_mengimplementasikan di tengah masyarakat dengan menggunakan pendekatan popularitas konsep yang selama ini dimiliki : Tawassut (moderat), Tasamuh(toleransi), Tawazun (seimbang) dan I'tidal (bersikap adil).
\end{abstract}

Kata Kunci : Nilai-Nilai Aswaja, Doktrin, Manhaj al-Fikr, Pluralisme, Ümat Islam

\section{A. Asal usul Aswaja}

Umat Islam pada masa Rasulullah SAW dalam situasi dan kondisi aman, tentram, damai, dan sejahtera, sedikit sekali persoalan yang berkembang di tengah masyarakat. Namun demikian bilamana terdapat problematika internal Umat Islam yang dilihat dari aspek agama, sosial budaya, ekonomi maupun politik, maka Rosulullah SAW senantiasa bisa memecahkan solusinya secara langsung maupun tidak langsung terhadap Umat Islam tersebut. ' Karena pada diri Rosulullah disadari maupun tidak, secara langsung maupun tidak langsung mendapatkan berbagai bisikan wahyu dari Allah SWT dalam mencari jalan keluar setiap persoalan yang berkembang di tengah komunitas masyarakat itu.

Dari sini, perjalanan Rasulullah SAW diatas, ditinjau dari aspek perkataan, perbuatan (sikap); atau bahkan keputusan-Nya dijadikan standar (ukuran) sahabat-sahabat Nabi yang populer dengan sebutan "Khulafaur Rosyidin" mereka adalah Abu Bakar As-Shidiq RA, Umar bin Khattab RA, Utsman bin Affan RA, dan Ali bin Abi Thalib $K W$. 
Oleh karena itu, pelacakan asal-usul konsep Aswaja secara substansi nilainya (baca: bukan secara formal atau resmi) sudah muncul pada masa Rosulullah SAW. Artinya, sebuah tradisi yang dikembangkan oleh Rosulullah SAW kemudian diikuti oleh para sahabat-Nya (mayoritas umat Islam). ${ }^{2} \mathrm{Hal}$ ini sesungguhnya, yang secara tidak langsung merupakan benih munculnya pemahaman Aswaja itu, kendatipun generasi pada saat itu belum sampai menjadikan ideologi (madzhab) secara formal yang terlembagakan (instansi). Tradisi-tradisi Rosulullah SAW diatas juga dijelaskan secara gamblang oleh salah seorang ulama senior NU KH. Ahmad Siddiq dengan istilah "Ajaran Islam Murni", artinya, ajaran islam yang murni sebagaimana diajarkan dan diamalkan oleh Rosulullah SAW bersama para sahabatnya. ${ }^{3}$

Sejalan dengan bergulimya waktu, ditengah masa Khulafaur Rosyidin, tepatnya kepemimpinan Khalifah dikendalikan oleh sahabat Abu Bakar AsShidiq RA dan Umar bin Khattab RA, mulailah terdengar fenomena-fenomena sosial, budaya, atau bahkan agama yang menjadikan silang pendapat, namun demikian, situasi dan kondisi tersebut bisa dikondisikan dan diselesaikan oleh Umat Islam bersama para tokohnya dengan baik. Kecurigaan, perdebatan yang mengandung perbedaan diantara mereka justru senantiasa bisa mengantarkan mereka dalam langkah-langkah untuk memajukan dan mengembangkan Islam secara kaffah itu sendiri (baca : Izzul Islam Wal Muslimin). Disamping itu mereka memahaminya dengan adanya rahmah (Ikhtilafu Ummati Rohmatun).

Namun demikian, ketika kepemimpinan Khilafah dikendalikan oleh sahabat Ustman bin Affan RA, berbagai persoalan mulai bemunculan, mayoritas para pengendali pemerintahan sudah beralih memiliki kecenderungan ke arah sifat-sifat Hidonistik (Kemewahan) dan materi Materialistik (kesenangan 'dunia) pada saat akhir kepemimpinan (khilafah) sahabat Ustman bin Affan RA; sifat-sifat (caracteristic) diatas bisa digambarkan dalam bentuk mengangkat para pembesar pemerintah dari kalangan sukunya atau bahkan pengusaha-pengusaha daerah. ${ }^{4}$ Dari sini angin kencang bërbagai fitnah yang dihembuskan seorang Pendeta besar Yahudi Yaman bernama Abdullah bin Saba' yang telah masuk Islam semakin menjadi-jadi dan berakhir puncaknya yaitu terbunuhnya seorang Khalifah yang saleh dan jujur ditempatnya pada tahun $35 \mathrm{H} .{ }^{5}$ Sesungguhnya, faham yang bertentangan dengan Aswaja sudah mulai berhembus sejak tahun $30 \mathrm{H}$ sampai pada tahun $35 \mathrm{H}^{6}$, sehingga faham ini dikenal dengan faham aliran Syi'ah.

Setelah sepeninggal Khalifah Ustman bin Affan RA (Khalifah Ke-3), kepemimpinan (khilafah) diberikan kepada sahabat Ali bin Abi Thalib KW, dari 
tahun $35 \mathrm{H}$ sampai $40 \mathrm{H}^{7}$. Ketika Khalifah Ali bin Abi Thalib $\mathrm{KW}$ menjabat sebagai Khalifah, beliau memikul tanggungjawab yang sangat berat, lebih-lebih harus berhadapan dengan ruang lingkup Umat Islam sendiri, dikarenakan beliau masih memiliki berbagai warisan termasuk persoalan dari pendahulunya. ${ }^{8}$

Pada kepemimpinan khalifah beliau, muncul peristiwa besar dalam sejarah Umat Islam yang akrab lebih dikenal dengan sebutan "Fitnatul Kubro" atau "Tahkim" (arbitrase), Romadhon 37 H/657 M di Daumat al-Jandal (antara Madinah dan Irak). ${ }^{9}$ Kesimpulannya yang terjadi pada saat itu adalah suatu pertempuran pemerintah yang sah di pihak sahabat Ali bin Abi Thalib KW, berhadapan dengan sahabat Muawiyah bin Abi Sufyan Gubernur Syam (Suriah), yang selanjutnya pertempuran itu dikenal dengan sebutan "Perang Siffin" pada tahun $37 \mathrm{H}$, kemudian sebelumnya juga terjadi pertempuran yang dipimpin oleh sahabat Ali bin Abi Thalib KW melawan Siti Aisyah istri Rosulullah SAW, yang lebih dikenal dengan sebutan "Perang Jamal" pada tahun $36 \mathrm{H} .{ }^{10}$

Bermula d ari persoalan Tahkim (Arbitrasi) diatas, s esungguhnya, pertentangan diantara mereka adalah persoalan yang bermuatan politik, pada akhirnya berubah menjadi persoalan I'tiqad (aqidah). Oleh karena itu, pada akhir kepemimpinan sahabat Ali bin Abi Thalib KW, sedikit banyak terdapat situasi dan kondisi yang tidak stabil dan kekacauan yang tidak bisa dihindarkan ditengah kalangan Umat Islam. Melainkan dari situasi dan kondisi yang penuh ketidakstabilan inilah, terdapat empat golongan kekuatan besar Umat Islam yang pada pekembangan berikutnya melahirkan firqah-firqah di tengah Umat Islam, pertama, golongan Syi'ah, mereka komunitas Umat Islam yang membela sahabat Ali bin Abi Thalib KW. Selanjutnya dikemudian hari bisa malahirkan bebagai sekte dalam Syi'ah. Kedua, Golongan Jabariyah (Fatalistik), mereka berkayakinan kejadian maupun segala sesuatu itu sepenuhnya kepada Allah SWT, pada perkembangan berikutnya, sebagai reaksi dari kelompok ini muncul sebuah nama kelompok yang disebut "Qodariyah", kelompok ini didirikan olehMuhammad Ali ibn Ali (Putra tunggal Ali bin Abi Thalib KW dari Khaulah al-Hanafiyah yang dikawin setelah Fatimah binti Rosulullah SAW wafat) yang juga dikenal sebagai embrio lahimya golongan "Mu'tazilah", kelompok ini diprakarsai oleh muridnya Muhammad al Hanafiyah, yaitu : Washil ibn Atho'." Ketiga, golongan Khawarij, mereka tidak sepaham dengan barisan kubu sahabat Ali bin Abi Thalib KW, maupun barisan kubu sahabat Muawiyah bin Abi Sufyan Gubernur Syiria pada saat itu, sebagai respon balik dari kelompok ini muncul gerakan suatu kelompok Umat Islam yang terkenal dengan sebutan "Murji'ah" mereka suatu komunitas Umat Islam yang tidak sepaham dengan kaum Khawarij tentang persoalan Iman dan Kufur. ${ }^{12}$ Keempat, golongan nertral, 
mereka moderat diantara berbagai aliran (madzhab) yang bermunculan di tengah masyarakat muslim, perlu diketahui bahwa kelompok mereka ini diantaranya adalah : Abdullah bin Umar ${ }^{13}$, Abdullah bin Abbas'", Abdullah bin Mas' 'ud. ${ }^{15}$

Merujuk berdasarkan kelompok-kelompok Umat Islam diatas, ketika memahami bahwa sesungguhnya persoalan-persoalan yang melahirkan perbedaan dan persengketan diantara mereka lebih dititik beratkan pada persoalan politik atas nama legalitas agama yang menjadikan pemahaman keyakinan mereka masing-masing, namun demikian, hanyalah bersifat emosional tidak terkendali, temporal, sesaat, lokalitas dalam upaya mempertahankan kelompok-kelompok mereka masing-masing. Oleh karena itu, berbagai kelompok (baca : firqah) tersebut ada yang mampu bertahan, atau bahkan sebaliknya pada saat itu juga.

Namun demikian, kita bisa menarik benang merah dari perjalanan berbagai kelompok (baca : golongan atau firqah) tersebut, ternyata masih terdapat orang-orang (kelompok) yang bersifat jujur, amanah dan mukhlis, tidak mau terseret dalam pertentangan politik, akan tetapi memiliki kecenderungan dalam memahami sunnah (baca : tradisi Nabi Muhammad SAW, berikut para sahabat beliau). Mereka itulah sesungguhnya sebagai embrio pemahaman aswaja yang hampir mendekati suatu ma'na alternatif selanjutnya, kelompok ini dikenal dengan sebutan "Netral" (kelompok ke empat dalam tulisan ini).

Generasi kelompok keempat diatas, diteruskan oleh generasi Ahmad bin Hambal (baca : Imam Hambali) ${ }^{16}$, beliau dikenal dengan sebutan "ahli Sunnah atau a hli Hadits", s ampai kemudian sebagian U lama Maghrib pernah. mengatakan "Madzhab itu milik Malik dan Syafi'I", sedangkan kepopulerannya milik Ahmad, maksudnya, madzhab para I mam Usul itu merupakan suatu madzhab seperti yang dikatakannya. ${ }^{17}$ Selanjutnya, Imam Ahmad ibn Hambal itu sebenarnya hidup ditengah ruang lingkup aliran Kaum Mu'tazilah, yang merupakan faham aliran resmi kekuasaan Bani Abbasiyah dan mendapat simpati, serta pengaruh besar didalamnya, kemudian sebagai puncak pengaruh aliran ini pada masa al-Ma'mun (198-218 H/813-833 M). ${ }^{18}$ Namun demikian, Imam Ahmad ibn Hambal memiliki akar yang sangat damai di tengah masyarakat, akhirnyå, beliau meskipun pernah dimasukkan penjara, akan tetapi tidak sampai dibunuh oleh penguasa, karena dikhawatirkan akan muncul kekacauan dan keributan di tengah masyarakat.

Selanjutnya, ketika kepemimpinan Umat Islam dikendalikan oleh al Mutawakkil (233-247 H/847-861 M), kondisi faham golongan Mu'tazilah sudah 
mulaii tidak diminati Umat Islam. Dengan demikian, sang Khalifah memiliki strategi mencari dukungan mayoitas Umat Islam, dan mereka itu pengikut Imam Ahmad ibn Hambal. ${ }^{19}$

Dari sini, pada saat kondisi dan situasi orang-orang awam kesulitan memahami konsep-konsep Mu'tazilah yang rasionalis dan filosofis, mereka merindukan ajaran-ajaran yang bersifat sederhana yang sejalan dengan sunnah Nabi Muhammad SAW dan tradisi para sahabat. Akhimya, lahirlah paham teologi baru yang berusaha menampung aspirasi masyarakat dengan berpegang teguh pada sunnah Nabi SAW serta tradisi para sahabatnya, kemudian ajaranajaran tersebut secara legal formal-subtansial dinamakan "Ahlus Sunnah Wal Jama'ah" (aswaja), yang secara resmi didirikan oleh tokoh baru bernama Abu Hasan al-Asyari (260 H/873 M-324 H/935) pada awal abad ke-9.

Perlu kita ketahui, sesungguhnya Imam abu Hasan al-Asy'ari sebelumnya penganut aliran Mu'tazilah, kemudian beliau menyatakan diri keluar dari aliran tesebut dan berbalik menentangnya: Hal ini didasarkan beberapa sebab. ${ }^{20}$ Periama, al-Asy'ari bermimpi bertemu R osulullah S'AW yang menyuruh meninggalkan aliran yang dianutnya itu dan selanjutnya ia diperintahkan untuk membela sunnah Rosulullah SAW. Kedua, al-Asyari tidak puas dengan jawaban dan penjelasan-penjelasan yang diberikan gurunya, al-Juba 'I, tentang berbagai. masalah-masalah keagamaan. Ketiga, al-Asyari melihat bahwa aliran Mu'tazilah tidak dapat diterima oleh umumnya Umat Islam yang bersifat sederhana dalam pemikiran, sementara ketika itu belum ada teologi lain yang dapat diandalkan, keempat, al-Asyari kalah bersaing dengan Abu Hasyim (anak al-Jaba'i) dalam menggantikan posisi al-Juba'i sebagai tokoh Mu'tazilah.

Sejak kelahiran aliran yang didirikan Imam Abu Hasan:al Asy'ari sampai sekarang juga dikenal di kalangan Umat Islam dengan sebutan "al-Asy 'ari atau Sunni". Selanjutnya, ajaran-ajaran al-Asy'ari ini tumbuh dan berkembang pesat di tengah masyarakat melalui generasi-generasi setelahnya (murid-murid) nya. Namun demikian, hampir bersamaan bergulirnya waktu dan sealiran pemikirannya, yaitu : aliran Maturidiyah yang didirikan oleh Abu Mansur Muhámmad al-Maturidi $(333 \mathrm{H} / 944 \mathrm{M})$ di Samarkand, aliran yang terakhir ini pendukung baru al-Asy'ari dan termasuk golongan Ahlussunnah Wal jama'ah:

Terakhir, dua golongan ini baik al-Asy'ari maupunal-Maturidi memiliki subtansi nilai-nilai yang di kembangkan yang dibuat rujukan Umat Islam oleh thariqah Ahlussunnah Wal Jama'ah, yaitu : Moderat (Tawasuth), I'tidal (Besikap Adil), Tawazun (Besikap Seimbang) dan Tasamuh (Bersikap Toleran) 
sehingga ia menolak segala bentuk tindakan dan pemikiran yang ekstrim (Tatharruf) yang dapat melahirkan penyimpangan dan penyelewengan dari ajaran Islam. ${ }^{22}$ Dalam pemikiran keagamaan juga dikembangkan keseimbangan (jalan tengah) antara penggunaan wahyu (naqliyah) dan rasio (aqliyah) sehingga dimungkinkan a komodatif t erhadap perubahan-perubahan di masyaakat sepanjang tidak melawan doktrin-doktrin yang dogmatis, ${ }^{23}$ meskipun keseimbangan itu tidak selalu benar berdiri di tengah antara wahyu dan akal, akan tetapi lebih condong pada wahyu dari pada akal (Taqdim al-Naql 'ala al-aql). ${ }^{24}$

\section{B. Pengertian Aswaja}

Pengertian Aswaja disini meliputi dua hal, pertama, pengertian Aswaja menurut pandangan para tokoh Nahdlatul Ulama'. Kedua, pengetian Aswaja menurit pandangan para tokoh yang sepaham dengan para tokoh Nahdlatul Ulama'

1. Pengertian Aswaja menurut para tokoh Nahdlatul Ulama'

a. Pengertian Aswaja menurut pandangan para ulama NU adalah "Umat Islam yang selalu berpegang teguh pada kitab Allah SWT (Al-Qur'an) dan Sunnah Rosul SAW, serta tata cara para sahabat Nabi SAW melaksanakan petunjuk Al-Qur'an dan Sunnah tesebut". ${ }^{25}$

b. Pengertian Aswaja menurut KH. Achmad Siddiq adalah "Suatu tajdid (Pembaharuan dan atau Pelurusan) jalan terhadap penyelewenganpenyelewengan, penyimpangan-penyimpangan, kekacauan-kekacauan pikiran, dan pendapat dalam memahami Al-Qur'an dan Hadits. ${ }^{26}$

2. Pengertian Aswaja menurut para tokoh yang sejalan dengan tokoh NU.

a. Pengertian Aswaja menurut pandangan Zamakhsyari Dhafier adalah: "Para pengikut tradisi Muhammad SAW dan Ijma' ulama". ${ }^{27}$

b. Pengertian Aswaja menurut pandangan KH. Sirojuddin Abbas adalah "I'tiqad sebagai I'tiqad yang dianut Nabi M uhammad SAW d an sahabat-sahabat beliau. ${ }^{28}$

c. Pengertian Aswaja menurut pandangan Ensiklopedi Islam adalah "salah satu aliran Teologi Islam yang timbul karena reaksi terhadap golongan Mu'tazilah, merupakan nama bagian aliran Asy'ariyah dan Maturidiyah karena mereka berpegang kuat pada sunnah Nabi Muhammad SAW dan juga merupakan kelompok mayoritas dalam masyarakat Islam". ${ }^{29}$ 
d. Pengertian A swaja menurut $\mathrm{p}$ andangan $\mathrm{H}$ arun Nasution a dalah "Penganut tradisi (kebiasaan) Nabi Muhammad SAW sebagaimana yang dilakukan oleh masyarakat mayoritas Umat Islam". ${ }^{30}$

' Dari berbagai pengertian Aswaja yang dikemukakan para tokoh diatas, telah banyak memiliki titik persamaan diantara ulama satu dengan yang lainnya. Artinya : pemahaman dan pengertian Aswaja itu sendiri masih memiliki makna yang kembali kepada tradisi-trsdisi Rosulullah SAW dan para sahabat beliau" oleh karena itu, bilamana ada paham-paham lain yang tidak sejalan dengan inti sari berbagai pengertian diatas, maka mereka termasukbukan kategori golongan Ahlussunnah Wal Jama'ah, seperti : Syi'ah, Mu'tazilah, Khawarij, Murji'ah dan lain-lain.

\section{Tujuan dan Guna Mempelajari Aswaja}

1. Tujuan Umun

a. Memberikan reaksi jalan tengah diantara dua golongan besar Umat Islam, yaitu : Golongan Qodariyah dan Jabariyah.

b. Memberikan dan menghadangajaran-ajaran Mu'tazilah yang memiliki kecenderingan akal semata, lebih-lebih al-Qur'an (wahyu) akan tunduk di bawah akal.31

c. Mempertahankan karakter Umat Islam, ketika Umat Islam pada saat itu di tengah berbagai aliran dan golongan yang sulit dipersatukan. Akhirnya, karakter Umat Islam ini digunakan Nahdlatul 'Ulama (NU) yang meliputi tiga hal :

1. Keseimbangan antara dalil agli (rasio) dan dalil nagli (al-Qur'an dan Hadits), dengan pengertian dalil aqli ditempatkan dibawah dalil naqli.

2. Berusaha sekuat tenaga memumikan aqidah dan campuran aqidah di luar Islam.

3. Tidak mudah menjalankan vonis musyrik, kafir dan sebagainya atas seseorang yang karena satu dan lain sebab belum dapat memurnikan aqidah semurni-murninya. ${ }^{32}$

2. Tujuan Khusus

a. Memahami, menghayati dan mengamalkan dasar-dasar keagamaan yang dipahami di lingkungan Nahdlatul Ulama sebagai berikut : ${ }^{33}$ 
1. Memahami faham keagamaan berdasarkan sumber ajaran Islam, yaitu: al-Qur'an, al-Ijma' dan al-Qiyas.

2. Memahami dan menafsirkan ajaran Islam dari sumber-sumbernya mengikuti faham Ahlussunnah Wal Jama'ah (Aswaja) dengan menggunakan pendekatan madzhab :

a. DibidangAqidah, mengikuti fahamAhlussunnah Wal Jama'ah yang dipelopori oleh A bul Hasan a l-Asy'ari dan Abu Mansur a lMaturidy.

b. Dibidang fiqh, mengikuti jalan pendekatan salah satu dari Madzhab Abu Hanifah an Nu'man, Malik bi Anas, Muhammad bin Idris Asy-syafi'i, dan Ahmad bin Hambal.

c. Dibidang tasawuf, mengikuti antara lain Junaidi al-Baghdady, dan Abu Hamid al-Ghozaly.

3. Memahami dan menjelaskan sebuah konsep, "memelihara nilai-nilai tedahulu yang sudah baik, dan mengambil nilai-nilai baru yang lebih baik"

b. Memberikan dan menjelaskan kaum tradisional menanggapi gerakan pembaharuan bahwa memahami Islam tidak cukup hanya berlandaskan al-Qur'an dan al-Hadits, tetapi harus melalui jenjang tetentu, yaitu Ulama Madzhab, Hadits (sunnah) dan akhimya kembali pada sumber utama alQu'an itu sendiri. ${ }^{34}$

3. Kegunaan (Faedah) Mempelajari Aswaja

1. Supaya bisa melakukan berbagai aktifitas di tengah masyarakat berdasarkan nilai-nilai kemasyarakatan yang bersumber pada Ahlussunnah Wal Jama'ah, yaitu watak moderat (tawasuth), bersikap adil (I'tidal) besikap seimbang (Tawazun), bersikap toleran (Tasamuh) ${ }^{35}$.

2. Supaya bisa merealisasikan amar ma'uf nahi mungkar di t engah kehidupan bermasyaakat, berbangsa dan bernegara, artinya : selalu memiliki k epekaan u ntuk mendorong perbuatan $y$ ang $b$ aik dan bermanfa'at bagi kehidupan bersama, serta menolak dan mencegah semua hal yang dapat menjerumuskan dan merendahkan nilai-nilai kehidupan. ${ }^{36}$

3. Supaya bisa menawarkan s emangat inklusifisme y ang bersedia membuka proses dialog, toleransi, rekonsiliasi, dan mengakui semua 
kelompok yang bersengketa sebagai umat yang satu. ${ }^{37}$ Akhirnya, bisa diterima oleh berbagai golongan di masyaakat dan berkembang dengan pesat. ${ }^{38}$

\section{Purna Wacana}

Konsep Aswaja merupakan alternative modal dasar untuk dijadikan pedoman dalam memotivasi dan menggerakkan umat manusia dalam aspek kehidupan. Memahami melalui konsep Aswaja ini akan dapat melahirkan subtansi nilai-nilai maknà yang dapat digunakan dalam menyelesaikan bentuk problematika yang berkembang di tengah realitas pluralitas masyarakat berbasis pesantren k hususnya, berikut berbangsa dan bérnegara pada umumnya disamping tuntutan situasi dan kondisi apapun.

Wallahu a 'lam bi al shawab!

\section{Footnote:}

' Mohammad Asrori Alfa, Makalah. Rekonstruksi Pemikiran Ahlus Sunnah Wail Jama 'ah Dalam Perspektif Ulama Kontemporer (Malang : PC PMII, 1997) Hlm.1

${ }^{2}$ Lihat, Harun Nasution, Teologi Islam, (Jakarta : Universitas Indonesia, 1986), $\mathrm{HIm} 64$

${ }^{3}$ Choirul Anam, Pertumbuhan dan Perkembangan Nahdlatul Ulama, (Sala : Jatayu, 1985), Hlm. 135.

${ }^{4}$ Sirojuddin Abbas, I'tigad Ahlussunnah Wal Jama'ah, (Jakarta : Pustaka Tarbiyah, 1994), hal.101. untuk selanjutnya disebut, Sirojuddin I'tiqad

s Ibid

${ }^{6}$ Ibid. hlm. 104

'Ibidhlm.104-105

${ }^{8}$ Lihat, Pendidikan Ke-NU-an (ASWAJA) : MTs/SMP, (Surabaya : LP.Ma'arif Jawa Timur, 1986, 3) hlm.40-41.

${ }^{9}$ Ensiklopedi Islam, (Jakarta : PT. Ikhtiar Baru Van Hoeve, 1984, vol.I) hlm. 186.

${ }^{10}$ Sirojuddin, I'tiqad, op.cit. hlm 106-109

"Said Aqiel Siradj, Makalah : Ahlussunnah Wal Jama'ah dan HAM iSuatu Terjemahan dari Visi Historis),(Malang :Unisma, 1997),Hlm.2-3.

12 Muhammad Abdul Hadi Al-Musri, Manhaj dan Aqidah Ahlussunnah Wal Jama'ah (Menurut pemahaman Ulama 'Salaf), (Jakarta : Gema Insani Press, 1992). Hlm. 180, untuk selanjutnya disebut, Muhammad, Manhaj. 
${ }^{13}$ Sirojuddin, op.cit. hlm. 106 (Lihat Ahmad Amin, Fajrul lslam, Cairo : Maktabah al Nahdhah al Misriyah, 1975), Hlm. 254-255.

${ }^{14}$ Abul A'la Al Maududi, "Khalifah dan Kerajaan", (Bandung : Mizan, 1996), hlm 181-182.

is Fathurrahman Alfa, Makalah : Ahlussunnah Wal Jama'ah sebagai Manhaj al Fikri, (Malang: PMII Koms. IAIN SA, 1993), Hlm.1

${ }^{16}$ Ensiklopedi Islam ...hlm. 79-80.

${ }^{17}$ Satatemen diatas, merupakan nukilan dari kitab "Manhaj as Sunnah" kemudian ditulis oleh Muhammad Abdul Hadi al Musri (Lihat Muhammad, Manhaj, op.cit, hlm.8788)

${ }^{18}$ Ensiklopedi Islam, op.cit. hlm. 186

${ }^{19} \mathrm{Ibid}$. hlm. 80

${ }^{20}$ Ibid. 187

- ${ }^{21}$ Ensiklopedi Islam, Vol 3, op.cit, Hlm 206

${ }^{22}$ Noer Iskandar Al-Barsamy, Perlunya Penerapan Bermadzhab Manhaji, (Aula, No. 9, September 1990, hlm. 80 dan lihat (Hazim, Doktrin Ahlussunnah Wal Jama'ah ) Surabaya : T.P, 1991), Hlm.2 ; Abu Zahid dan Kerabat Aula (Peny), Pemikiran KH. Achmad Siddiq, (Surabaya : Yayasan Aula Jawa Timur, 1992) hlm. 44)

2. MA. Sahal Mahfudz, Pengembangan Ahlussunnah Wal Jama'ah. dalam Perkembangan Didiplin Keilmuan Sekarang, (Aula, No. 12 Desember, 1985 hlm. 2627)

${ }^{24}$ Noer Hadi Iskandar, Bingkai Aswaja Bermadzhab, (Aula, No. 3 Maret 1997), HIm 24

${ }^{25}$ Ach. Masduki, Konsep Dasar Pengertian Ahlussunnah Wal Jama'ah, (Surabaya : Pelita Dunia, 1994), hlm. 38, Badrun Alina dan Humaidy, Humaidy dan Ridwan Fakla AS (ed),Biografi 5 Rais Am Nahdlatul Ulama, (Yogyakarta : LTn-NU bekerjasama dengan Pustaka Pelajar, 1995),Hlm. 5.

${ }^{26}$ Achmad Siddiq, Pedoman Berpikir Nahdlatul 'Ulama', (Surabaya : Forum Silaturrahmi Asrjana Nahdlatul 'Ulama-FOSSNU Jatim, 1992), hlm. 16.

${ }^{27}$ Zamakhsyari Dhafier, Tradisi Pesantren Studi Tentang Pandangan Hidup Kyai, semula Tesis ph.D, pada Austrakan National University Canberra tahun 1980, Jakarta : Lembaga Penelitian, Pendidikan dan Penerangan Ekonomi-LP3ES, 1983), hlm 148 .

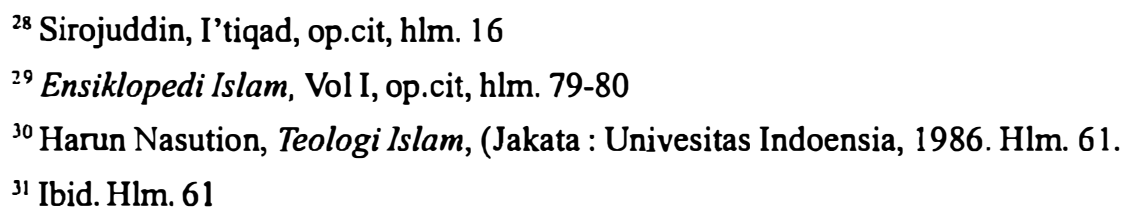

${ }^{28}$ Sirojuddin, I'tiqad, op.cit, hlm. 16

${ }^{29}$ Ensiklopedi Islam, Vol I, op.cit, hlm. 79-80

${ }^{30}$ Harun Nasution, Teologi Islam, (Jakata : Univesitas Indoensia, 1986. Hlm. 61.

${ }^{31}$ Ibid. Hlm. 61 
32. Choiul Anam, Pertumbuhan, op.cit. Hlm. 152 (Lihat, Einar Martahan Sitompal, M.Th, NU dan Pancasila, (Jakarta : Pustaka Sinar Harapan, 1989), Hlm. 73). Untuk selanjutnya disebut Einar, NU dan Pancasila.

${ }^{33}$ Disarikan dari Pengurus Wilayah NahdlatulUlama Jawa Timur, Khittah Nahdlatul Ulama', (Surabaya : Lajnah Ta'lif Wan Nasyr, tt) Hlm. 10-11, (Lihat Einer, NU dan Pancasila op.cit, hlm.70

${ }^{34}$ Einer, Ibid, hlm. 69-70

${ }^{35}$ Muzammil Qomar, NU Liberal : Dari Tradisi Sosialisme Ahlussunnah Wal Jama'ah ke Universilisme Islam, (Bandung : Mizan, 2002), hlm. 65.

${ }^{36}$ PWNU Jawa Timur, Khittah, op.cit, hlm. 15-16

${ }^{37}$ M. Ali Haidar, NU : Wawasan Sosio Kultural dan Keagamaan, (Aula, No. 3 Maret, 1994) hlm. 57

${ }^{38}$ Hazim, Doktrin Ahlussunnah, op.cit. 62 .

\section{DAFTAR PUSTAKA}

Abbas, Sirojuddin, 1994.I'itiqad Ahlussunnah Wal Jama 'ah, Jakata : Pustaka Tabiyah. Abdul Hadi al-Musri, Mohammad, 1992. Manhaj dan Aqidah Ahlussunnah Wal Jama 'ah (Menurut Pemikiran Ulama Sala), Jakarta : Gema Insani Press.

Abu Jahid dan Kerabat Aula (Peny.), 1992.Pemikiran KH. Achmad Siddiq, Surabaya : Yayasan Aula Jawa Timur.

Al-Barsany, Noe Iskandar, 1990.Perlunya Penerapan Bermadzhab Manhaji, Aula, No.9, September.

Al-Maududy, Abul A'la, 1996.Khalifah dan Kerajaan, Bandung : Mizan.

Amin, Achmad 1975. Fajrul Islam, Cairo : Maktabah an-Nahdhiyah al-Misriyah.

Anam, Choirul 1995.Pertumbuhan dan Perkembangan Nahdlatul 'Ulaina 'Sala : Jatayu.

Aqiel Siadj, Said, 1997.Makalah : Ahlussunnah Wal Jama'ah dan HAM(Suatu Tinjauan dari Visi Historis), Malang : UNISMA.

Asrori Alfa, Mohammad, 1997.Makalah : Rekonstruksi Pemikiran Ahlussunnah Wal Jama 'ah dalam Perspektif Ulama Kontemporer, Malang : PC. PMII.

Badrun Alaina dan Humaidy, 1995.Biografi 5 Rais Am Nahdlatul Ulama ', Yogyakarta, LTn.NU bekerjasama dengan Pustaka Pelajar. 
Dhafier, Zamakhasyari 1983.Tradisi Pesantren Studi Tentang Pandangan Hidup Kyai, Semula Tesis $\mathrm{PhD}$, pada Austrakin National University Canberra Tahun 1980, Jakarta : Lembaga Penelitian, Pendidikan dan Penerangan Ekonomi-LP3ES.

Ensiklopedi Islam, 1984. Jakarta : PT. Ikhtiar Baru Van Hoeve (vol.I).

Fathurrahman, Alfa, 1993.Makalah : Ahlussunnah Wal Jama'ah sebagai Manhaj alFikr, Malang : PMII Koms. IAIN SA.

Haidar, M.Ali 1994. NU : Wawasan Sosio Kultural dan Keagamaan, Aula, No.3 Maret. Hazim, 1991.Doktrin Ahlussunnah Wal Jama'ah :T.P.

Iskandar, Noerhadi, 1997.Bingkai Aswaja Bermadzhab, Aula, No.3 Maret.

M.A. Sahal Mahfudh, 1 985. Pengembangan A hussunnah Wal Jama'ah dalam Perkembangan Disiplin Keilmuan Sekarang, Aula, No. 12, Desember.

Másduki, Achmad 1994.Konsep Dasar'Pengertian Ahlussunnah Wal Jama'ah. Surabaya : Pelita Dunia.

Pendidikan Ke NU-an (Aswaja) : MTs/SMP, 1986.Surabaya : LP. Ma'aif Jawa Timur.

Penguus PWNU Jawa Timur, Khittah Nahdlaul 'Ulama'. Surabaya : Lajnah Ta'lif Wan Nasy, tt.

Qomar, Muzammil 2002. NULiberal : Dari Tradisionalisme Ahlussunnah Wal Jama'ah Ke Universalitas Islam, Bandung : Mizan.

Siddiq, Achmad 1992.Pedoman Berfikir Nahdlatul 'Ulama', S urabaya : Forum Silaturrahmi Sarjana Nahdlatul Ulama'-FOSSINU Jawa Timur.

Sitompul, Einar Martahan, 1989.NU dan Pancasila, Jakarta : Pustaka Sinar Harapan.

- Dosen tetap Universitas Islam Negeri (UIN) Malang dan peserta program Doktor PPS IAIN Sunan Ampel Surabaya. 